\title{
Two Unreported Cartilagines Sesamoidea in the Elbow of the Dog
}

\author{
Dos Cartílagos Sesamoideos no Reportados en el Codo del Perro
}

Julio Gil G.* \& Ricardo Olivares P-M**

GIL, J. \& OLIVARES, R. Two unreported cartilagines sesamoidea in the elbow of the dog. Int. J. Morphol., 34(2):451-453, 2016.

SUMMARY: Two unreported sesamoid cartilages were found inside tendon of insertion of both muscle biceps brachii and muscle brachialis in the dog. This find adds remarkable facts envolving Anatomy, Comparative Anatomy and Clinic and Biomechanics of the elbow joint in the dog. Statistics also emphasize the importance of traumatological incidences on elbow joint in veterinary.

KEY WORDS: Sesamoid; M. biceps brachii; M. Brachialis; Elbow; Joint.

\section{INTRODUCTION}

Sesamoid cartilages and ossa sesamoidea are accessory bone structures related to some muscles. Sesamoid cartilages and ossa sesamoidea usually form inside tendons, but may also develop inside ligaments situated under tendons (Sullivan, 1962; Evans \& Miller, 1993).

Functionally, sesamoidea bodies protect tendons that cross over bone prominences, or/and increase the surface area for attachment of tendons, or/and redirect the effective forces of tendons (Evans \& Miller).

The elbow joint has a sesamoid bone inside the tendon of origin of M. supinator (Evans \& Miller; Constantinescu \& Constantinescu, 2009) or inside the collateral lateral ligament of elbow joint (Sisson et al., 1982; Dyce et al., 2010; Nickel et al., 1986).

\section{MATERIAL AND METHOD}

Fifteen mixed breed dogs were used, 9 males and 6 females. The bodies were provided by the Animal Protection Service of Zaragoza City Council. Neither abnormalities nor previous clinical alterations were detected in any of them.

Preparation of corpses was performed by technical staff of the Department of Anatomy, Faculty of Medicine Veterinary, University of Zaragoza, Spain. Both right and left thoracic limbs of each animal were used for a total of 30 dissected and studied elbow joints.

We obtained pieces from tendon of insertion of $M$. biceps brachii, and tendon of insertion of $M$. brachialis. Later, pieces of tissues were obtained following conventional procedures for optical microscopy. Sections $5 \mu$ m thick were stained with Hematoxilin and Eosine Mayer's staining method (Bacha \& Wood, 1990).

\section{RESULTS}

After thirty elbow dissections, a sesamoid cartilage was found inside each tendon of insertion of $M$. biceps brachii (Fig. 1). This structure was first detected by palpation and further dissection of the tendon. We also carried out histology confirmation (Fig. 2) by mean Hematoxilin and Eosine Mayer`s staining method (Bacha \& Wood).

Tendon of insertion of $M$. biceps brachii splits into two parts (Fig. 1). One part ends in a small tuberosity in the ulna, the other part ends in the radial tuberosity (Gil et al., 2005).

Another sesamoid cartilago was found in each tendon of insertion of M. brachialis (Fig. 1). This structure was first detected by palpation and further dissection of tendon.

\footnotetext{
* Department of Anatomy, Embryology and Animal Genetics, Faculty of Veterinary Medicine, Universidad de Zaragoza, Zaragoza, Spain.

** Department Animal Pathology. Faculty of Veterinary Science and Livestock, Universidad de Chile, Santiago, Chile.
} 
Furthermore, we performed histology confirmation by mean Hematoxilin and Eosine Mayer`s staining method (Bacha \& Wood).

Tendon of insertion of M. brachialis ends on pars cranialis and medialis of radius and ulna (Fig. 1). It passes between the two parts of tendon of insertion of M. biceps brachii (Gil et al.).

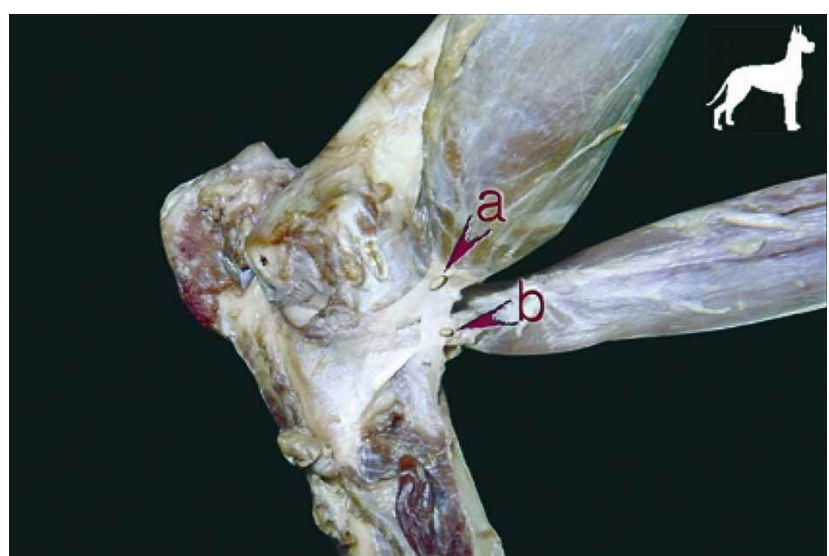

Fig. 1. Dog left elbow. Medial view (cartilagines sesamoidea are depicted in the places where they can be found). Cartilago sesamoidea in tendon of insertion of muscle biceps brachii (a). Cartilago sesamoidea in tendon of insertion of muscle brachialis (b).

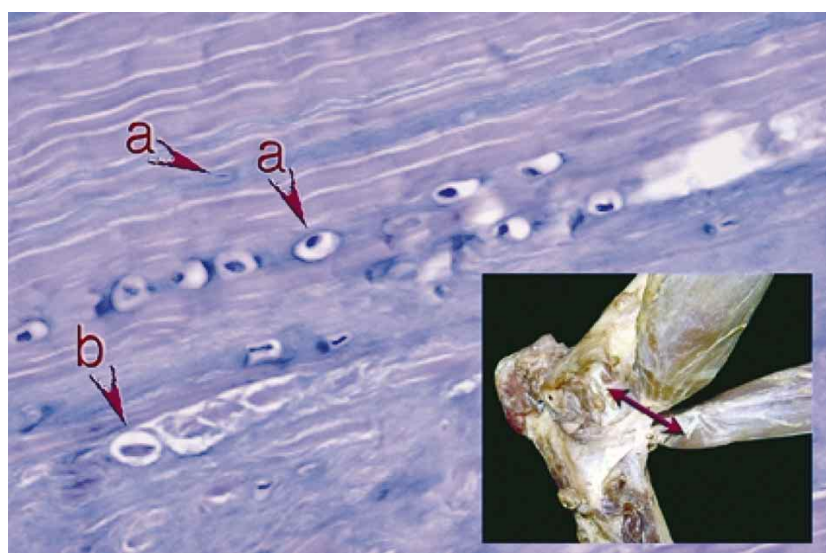

Fig. 2. Tendon of insertion of muscle biceps brachii section (small figure). Optical microscopy $400 \mathrm{X}$ and $5 \mu \mathrm{m}$ section thick, Hematoxilin and Eosine Mayer's staining Method. Chondroblast (a), chondrocyte (b), from tendon with cartilago sesamoidea.

\section{DISCUSSION}

Anatomically, these findings add more knowledge about structure and organization of elbow region components in the dog. In terms of comparative anatomy, these data serve to indicate you specific differences in the dog with regard to other carnivore species (Schaller, 1996).
The reported findings also contribute with data for traumatological procedures on suture at the ending tendons of M. biceps brachii and M. brachialis in the dog. They also provide more accurately information to avoid false diagnostic interpretations when more powerful techniques than traditional X-rays are used, like TAC or MR, that could be the case if these sesamoid bones are confused with strange bodies or the like (Hornof et al., 2000; Remy et al., 2004).

Biomechanically, these results stand out in relief functional differences of $M$. biceps brachii and $M$. brachialis in the dog with regard to other species. Finally, it is always scientifically prominent to contribute new and original information about gross anatomy of a familiar species such as the dog.

A descriptive finding like this is not a very debatable subject, but it is a remarkable feature regarding anatomical knowledge on elbow joint of the dog at present, a joint that shows far reaching statistical importance in veterinary traumatology.

GIL, J. \& OLIVARES, R. Dos cartílagos sesamoideos no reportados en el codo del perro. Int. J. Morphol., 34(2):451-453, 2016.

RESUMEN: Dos cartílagos sesamoideos no reportados se encontraron en el interior del tendón de inserción de los músculos bíceps braquial (M. Biceps brachii) y Braquial (M. Brachialis) en el perro. Este hallazgo se suma a importantes hechos que comprometen la Anatomía, Anatomía Comparada, Clínica y Biomecánica de la articulación del codo en el perro. Además, la casuística veterinaria también hace hincapié en importantes incidencias traumatológicas en dicha articulación.

PALABRAS CLAVE: Sesamoideo; M. Biceps brachii; M. Brachialis; Codo; Articulación.

\section{REFERENCES}

Bacha, W. J. \& Wood, L. M. Color Atlas of Veterinary Histology. Philadelphia, Lea \& Febiger, 1990.

Constantinescu, G. M. \& Constantinescu, I. A. A clinically oriented comprehensive pictorial review of canine elbow anatomy. Vet. Surg., 38(2):135-43, 2009.

Dyce, K. M.; Sack, W. O. \& Wensing, C. J. G. Textbook of Veterinay Anatomy. St. Louis Mo., Saunders/Elsevier, 2010.

Evans, H. E. \& Miller, M. E. Miller's Anatomy of the Dog. 3rd ed. Philadelphia, W. B. Saunders, 1993. pp.243-7. 
Gil, J.; Gimeno, M.; Laborda, J. \& Nuviala, J. Anatomía del Perro. Protocolos de Disección. Barcelona, Masson, 2005. pp.55.

Hornof, W. J.; Wind, A. P.; Wallack, S. T. \& Schulz, K. S. Canine elbow dysplasia. The early radiographic detection of fragmentation of the coronoid process. Vet. Clin. North Am. Small Anim. Pract., 30(2):257-66, 2000.

Nickel, R.; Schummer, A.; Seiferle, E.; Wilkens, H.; Wille, K. H. \& Frewein, J. The Anatomy of the Domestic Animals. Vol. 1. Berlin, Springer Verlag, 1986. pp.183.

Remy, D.; Neuhart, L.; Fau, D. \& Genevois, J. P. Canine elbow dysplasia and primary lesions in German shepherd dogs in France. J. Small Anim. Pract., 45(5):244-8, 2004.

Schaller, O. (Ed.). Nomenclatura Anatómica Veterinaria Ilustrada. Zaragoza, Acribia, 1996. pp.84.

Sisson, S.; Grossman, J. D. \& Getty, R. Sisson y Grossman Anatomía de los Animales Domésticos. Barcelona, Salvat, 1982. pp.1649-81.

Sullivan, G. E. Anatomy and embryology of the wing musculature of the domestic fowl (Gallus). Austral. J. Zool., 10:458-518, 1962.
Correspondence to:

Dr. Ricardo Olivares PM

Departamento de Patología Animal

Facultad Ciencias Veterinarias y Pecuarias

Universidad de Chile

Av. Santa Rosa11735, La Pintana

Santiago

CHILE

Email: rolivare@uchile.cl

Received: 15-05-2015

Accepted: 28-03-2016 